\title{
STEPS ON LIFE CHANGE AND SPIRITUAL TRANSFORMATION: THE PROJECT OF THE SELF
}

\begin{abstract}
ANDRADA TOBIAS 1
ABSTRACT. The aim of the present paper is to analyse how individuals in contemporary Romania come to adopt a new life-style centred on the self and how new forms of spirituality contribute to this project. In order to document how powerfully immersed alternative forms of spirituality (yoga practices, transcendental meditation, bioenergy, holistic medicine etc.) and subjectification techniques (personal development, motivational practices) look like for people in Romania, I have combined participant observations with semi-structured indepth interviews. First of all I have reviewed the literature on spirituality and self-development and overviewed the specific techniques of subjectification. These techniques have the power to change the individual's view of life and have elements that serve the neoliberal governmentality. To continue, I have attended courses and workshops centred on spiritual development to uncover the communalities between literature and discourses on change. I was mainly interested in analysing the discourse of trainers, speakers and religious guiders and outlining the participants' experiences, while understanding how they utilise the knowledge and support given throughout these courses when trying to enhance their day-to-day lives and careers. ${ }^{2}$
\end{abstract}

Keywords: spirituality, self-development, governmentality

The public space is invaded by more and more discourses on the need for continuous self-development, in order for people to be able to survive in today's highly demanding and competitive living and working conditions. According to these, the individuals who are interested in creating happiness, success, efficiency and balance in their personal and work life are expected to self-refer to activities that support personal development. This increasing interest has created a huge sector for personal development and various programs and

${ }_{1} \mathrm{PhD}$ candidate in Sociology, Babeș-Bolyai University Cluj-Napoca, e-mail: andradatoby@yahoo.com.

2 This work was supported by a grant of the Romanian National Authority for Scientific Research and Innovation, CNCS - UEFISCDI, project number PN-II-RU-TE-2014-4-2515. 
materials have been elaborated (Binkley, 2007, 2011). In this context, different forms of spirituality have been developed as accessible programs to serve this need for self-development. Also, self-development programs and books have provided instructions for people by referring to their entire existence; they offer participants knowledge, techniques and successful models for realizing their individual potential. This message can come in different forms, for example experts on spiritual programs focus their discourses on the link between the universe and self; the subjects are encouraged to follow their individual paths in the universe on their own. My remark is that one's own path is usually understood according to what 'society' believes to be true. What I have found in my fieldwork is that many discourses have a common source of ideology on self-development. This transformation of the self implies ways of experiencing the reality rather than working on changing the reality (Miller and Rose, 2008). The practice of personal and spiritual development can offer new attitudes and strategies for practitioners to work continuously on themselves in the current economic conditions of neoliberal world. Making this argument, I found reliable Foucault's notions of governmentality and technologies of the self.

For Foucault, governmentality refers to the 'conduct of conduct' which ranges from governing of others in all aspects of life to governing of the self (Foucault, 1991). For hermeneutic purposes, Miller and Rose (2008) propose three different 'families' of governmentalities according to Foucault. The first one, named classical liberalism should be analysed as a mode of government, not merely a philosophy. In this case, the state limits itself from sectors of private life, market or civil society. At the same time, it cannot be ignored that the political apparatus is dependent on the activities of multiple external governing agents, like church, charitable organizations or trade unions. But the capacity of these comes under question when the political apparatus begins to extend its obligations into new spheres. In the 19th century the place of classical liberalism was replaced by governing from the social point of view. It was grounded in the argument that social government was necessary to combat the market individualism and the communist revolution. This was the original third or middle way to save private enterprise, to transform subjects into social citizens with social rights. [The governing from the social point of view] "depended heavily on the invention of new professionals of the social and new forms of inculcation of civility into citizens especially via home and domestication" (Miller and Rose, 2008: 17).

Foucault highlights the importance of the link between what he calls the technologies of the self (the creation of the individual subject) and the technologies of domination (the formation of the state) in the third 'family of governmentalities'. Named by Miller and Rose (2008) advance liberalism, usually 
known as neoliberalism, "it took shape in the last three decades of the twentieth century, although it was prefigured by the neoliberal thinkers such as Hayek in the immediate post-war period" (Miller and Rose, 2008:18). Now, governing is more than simple top-down power relations. Governing bodies view clear norms, fear and violence as being much less effective than employing more subtle forms of control (Hefner, 2010). The emergence of new strategies of activation and responsibilization of individuals are visible; certain conceptions of subjectivity from psychology are now central and act in the name of the idea of freedom. In this context, self-control becomes an important tool linked to economic sector and political rules.

[Technologies of the self] permit individuals to effect by their own means or with the help of others a certain number of operations on their own bodies and souls, thoughts, conduct, and way of being, so as to transform themselves in order to attain a certain state of happiness, purity, wisdom, perfection, or immortality (Foucault, 1988:18).

These technologies are not invented by subjects themselves but rather are "proposed, suggested and imposed on them by one's culture, society and social group" (Foucault, 1991:11). What appears to be individual choice is meant for the benefit of the state. In other words, neoliberalism implies structures of power by which governance is aligned with the personal capacities of the individuals. It is not just related with the idea of controlling, disciplining, normalizing or reforming subject; it is also related with the idea of making people more intelligent, happy, healthy, productive, docile, enterprising, fulfilled and empowered (Rose, 1998). Neoliberalism relies on the notion of responsible, rational individuals who are able to take responsibility for their lives and encourages them to see themselves as active subjects with entrepreneurial initiatives. As Rose (1998) argues, governing through the freedom and aspirations of the subjects makes it possible to govern in a liberal-democratic way, in the sense that self-governing capabilities are installed in free individuals in order to make them use their own ways of conducting and evaluating themselves. These techniques work "under the authority of experts who claim that the self can achieve a better and happier life through the application of scientific knowledge and professional skills" (Rose, 1998:157). Based on these arguments, I will analyze how a significant part of spiritual development programs and discourses reproduce certain types of subjectivity specific to neoliberal governmentality. I want to stress that my observation is based on the evidence that a significant number of subjects use techniques from spirituality practices to potentiate specific areas appreciated by neoliberalism, but we cannot reduce all the existent forms of spirituality to this alone. The existence of resilience groups of spiritual practitioners that are distant from the neoliberal agenda can not be denied, but the 
comparison of both categories can make the object of another discussion. My focus is on the similarities between the neoliberal agenda and the specific techniques of subjectification from the spiritual field, on how different forms of practices have similar purposes with those from the neoliberal agenda.

I began fieldwork on spiritual transformation several months ago and once I became familiar with a part of the literature on personal and spiritual development, I have delved into the surprisingly diverse web of programs available in this field in Romania. To understand what spiritual transformation means for practitioners I began to frequent different courses and seminars addressing the vast topic of spirituality. Besides attending courses, a great part of fieldwork was centred on interactions with practitioners and providers of spiritual services. My presence at these programs represented a necessary introduction towards understanding how individuals come to adopt a new life-style centred on the self, while re-evaluating their priorities during their implication in spiritual activities. The fieldwork revealed how practitioners of different forms of spirituality develop a perspective centred on the self. This perspective allows individuals do clearly distinguish themselves from those around them and to find motivation and resources within themselves for everyday life. In the meantime, they learn to become responsible for all the aspects of their lives, especially their happiness and well-being. Having said these, I am interested in how practitioners relate the changes of the self during the process of spiritual transformation and I identify what community dynamics, interactions and individual behaviours contribute to this. What needs to be brought to the fore is that some principles of governing in neoliberalism are to be found in the project of spiritual transformation as well.

This project will focus on those forms of spirituality that occurred in Romania in the past two decades, since the process of cultural and economic globalization has made the spiritual experience a psychological and individual one. From a shared system of believes and customs that established clear norms in society to personalized and syncretic forms of spirituality that offer individualized comfort, these spiritualities could emphasize a specific way of imagining productive subjectivity, one that helps the subject to be more motivated, more efficient and competitive (Binkley, 2007). In addition to that, spirituality implies techniques to accomplish a new self, one that is capable of self-management, responsible for its own life and able to deal with the new neoliberal condition (Carette and King, 2005). As mentioned before, in this context, the accomplishment of a new self requires a massive change of life. My fieldwork shows how different discourses on change reveal similar aspects that need to be improved in the process of self-development. The aim of this paper is to analyse how different actors - practitioners and authors in the field - 
discuss and understand the process of change and how they appropriate certain techniques from different fields of spirituality that have the capacity to improve certain elements distinct for neoliberal governmentality (Binkley, 2014; Heelas, 2008; Urban 2016). I will take into discussion the elements that need to be changed in the process of self-development; the list is not exhaustive, but points out the most noted aspects that were identified during my research as: the necessity of living in the present, the view on happiness, the increasing degree of self-confidence and the ability of being responsible for oneself. My empirical analysis shows that for subjects, working on these aspects contributes to their relationship to self and society. The transformation of the self implies a holistic approach, one that is aiming equally at the mind, body and soul, and is directly manageable by the individual; this change claims a re-evaluation of perspectives on self, happiness, present, responsibility, society and work.

I will argue in the empirical section that the necessity of living in the present or the spirit of presentism (Heelas in Rose, 2007) has become essential in the neoliberal society, a task eminently individual to find within oneself the ability to change the way of relating to past, present and future. According to this view the individual learns mental techniques through which one can be emancipated from the past and future and become a spectator of one's own mental processes, holistically in the here-and-now (Heelas, 2008). An aspect strongly connected to presentism is the improvement of happiness. The new discourse on happiness is remarkably prominent in the therapeutic culture of today. This notion of happiness requires repeated intervention in one's thinking, until the person gradually appropriates the new state of being. The personal development project requires one to Don't worry. Be happy!; another prerequisite is also that of being Happy, Healthy and Wealthy. These three attributes can be acquired through one's own strength; they do not appertain to the social context or the social origin of the individual. Today, almost all over the world, happiness and the degrees it can achieve are measured; happiness can be directly manageable and thus it becomes 'material', just as a muscle (Binkley, 2011) whose mass you can grow through physical exercise. In his book Happiness as an Enterprise: An Essay on Neoliberal Life, sociologist Sam Binkley brings together a conceptual problematic surrounding the practice of government in contemporary neoliberal societies with an extended empirical inquiry into the discourse of happiness, as constituted in popular texts especially on the topic of positive psychology. Based on the theoretical writings of researchers in the field of governmentality studies, Binkley views happiness as a technology but also as an enterprise of self-development. "It represents one of the chief instruments of neoliberal government, the very leitmotif of neoliberal life itself and [...] its most radical extension into the realm of private existence" (Binkley, 2014:4). 
The project of the self also implies the change of attitude on the subject's self-confidence and responsibility. The individual can learn different techniques that help him/her to increase self-confidence and at the same time to re-evaluate his/her responsibilities with implication on personal and professional relationships. According to Nikolas Rose (2007), the principles of governing in liberalism and democracy have a significant role in the project of changing the self, especially on self-confidence and responsibility. One of the main ideas is that individuals are free and responsible for their freedom. Contemporary human subjects, at least when they are accorded the status of adults, are obliged to be free (Schwartz, 2000; Urban, 2016) in the psychological sense. Binkley (2007), Rose (2007) and Urban (2016) are sceptical about the promised 'freedom'. In their studies, the authors explain how this freedom implies a greater individual responsibility and a change of perspective on self-confidence. The subject needs to be confident in his/her ability to improve all the aspects of his/her life and is the only one responsible if these occur or not. Self-confidence can be used to improve other aspects like efficiency or communication, valuable in the contemporary society, in day-to-day and work-life. The foregoing aspects envisioned by the change of the self are interrelated and have the capacity to determine other changes in the relationship to work, to society as a whole and most important to self. These changes help the subject to remain - or to become well anchored in the urban contemporary society.

To understand how powerfully immersed alternative forms of spirituality (yoga practices, transcendental meditation, bio-energy, holistic medicine, newage movements etc.) and subjectification techniques (personal development, motivational practices) are among people in contemporary Romania, I have combined participant observations with semi-structured in-depth interviews. I have analysed 34 interviews, conducted between April and November 2016 with people preoccupied with spiritual development, both consumers and providers of spiritual services. The interviews were conducted in two major cities in Romania, where the number of consumers, programmes and specialists on spirituality are spectacularly popular. The phenomenon is visible in other major cities in Romania as well, but I chose to do my fieldwork in these two places due to the abundance and accessibility of the providers and consumers of such services. All the selected respondents have higher education and are living in one of the selected cities; 27 of them are practitioners and seven of them are working in one of the spiritual branches. In the same period I have attended four courses on spiritual development and self-development and for nine months I have done fieldwork on weekly workshops and spiritual sessions offered by a spiritual centre. I was mainly interested in analysing the discourse of spiritual guides and outlining the participants' experiences, while understanding 
how they utilise the knowledge and support given throughout these courses when trying to enhance their day-by-day lives and careers. I have also done content analysis on a number of 20 books of spiritual development. The selection was made based on recommendations of practitioners and professionals in the field. All the selected titles are highly relevant for the subjects of my research, and some of them are alleged by these readers to have the power to change their life and spirituality. The list of selected titles comprises both international and Romanian authors. The notoriety of the author was however not the main criterion of selection. I was mainly interested to read what came highly recommended from within the field and to uncover similarities on the discourses about change. For example, in the books authored by Romanians, it is readily apparent central ideas are taken from the international field of spiritual development books.

In order to understand the ways in which meditation, yoga practices or other programs focused on spirituality can enhance the process of selftransformation, I participated in the activities of an organization I will refer to as 'The Spiritual Centre', in order to ensure its confidentiality. I was interested in understanding what drove individuals to take part in these activities and what are the perceived personal and professional benefits of pursuing these activities from their point of view. This organization has not emerged from a local initiative, but an international one. Almost half of the organization's staff is foreign and they have come to Romania precisely because they perceived here a huge interest for spirituality. Following the friendship between practitioners of various forms of holistic spirituality from Romania, Australia, USA, Hungary and Spain the desire has been born: 'to share with those around us the experience of awareness and personal transformation. We wanted to offer an alternative environment favorable for individual development' (A., 32 years old, yoga trainer). In just two years, the projects of "The Spiritual Centre" became attractive for non-practitioners by offering diverse services 'for mind, body and spirit'. Here, one can find specialists with international credentials and international experience in life-coaching in multinational companies. The members are comparing the organization 'to an incubator in which you'll live your transformative experience in a conscious, sustainable and authentic way, an ecosystem for personal development' (Y., 41, trainer on different forms of spirituality).

The programmes are successful in introducing, in a very accessible manner, elements of spirituality into the lives of individuals who have not had interest for these beforehand. Unlike many other programs in which participants have a projection or certain expectations about what will happen, many of those attending programmes here have come out of curiosity, accompanied by an acquaintance who has also attended the spiritual centre. Most of them had no 
knowledge of spirituality and not necessarily an interest into this field before, but desired to improve or to change themselves. The manner in which all of these programs are conducted - be it yoga, mindfulness, holotropic breathwork manages to capture the public in a colossal manner. The declared goal of "The Spiritual Centre" is not to attract large numbers of people, but rather to target some individuals that afterwards have the capacity to implement the holistic technology of self-fulfilment in other spaces, such as companies. For them, personal examples of revitalized life are the most important. The perception of a generalized state of well-being is common, maybe even at the very first meeting. The fascination of all of these programs is amplified by the fact that they highlight each and everyone's inner capacity for self-control over their own inner states and for knowledge of the 'authentic self'. The common ground is the considerable improvement of the inner state, a generalized sense of well-being, more concretely expressed through: excellent self-knowledge, confidence in one's own strength, concentration, efficiency, balance, better time management, new understandings and connotations for experiences and peace. Participants are always grateful towards these self-development programs, but each individual is convinced that improvement depends on each person's involvement and open-mindedness. The ultimate promise of all these programs is mastering certain individual techniques and practices through which the individual can easily fulfil his/her goals, while discovering one's potential and identifying the areas in which one can become fully performant.

As Heelas (2008) remarked and is consistent with what I have found in the interviewees' discourses is that each person has to be responsible for his/her own conscience. Spiritual development comes with the need to detach from what others want for you; only the 'self' is responsible to choose its own path. They state that the way to achieve the goal is also one's responsibility, regardless of the process being easy or not. Examples that I was given have often emphasized 'success', 'performance' and 'prosperity' and were direct references to the corporate environment: 'You cannot become a leader, more so a good leader, if you don't start from the bottom, if you don't know the needs of beginner employees and what motivates them' (Y., 41 years old, man, trainer on different forms of spirituality). Also, in many of the meetings that I have attended discussions were centred on workplace satisfaction, beyond material satisfaction, and this we were told does not necessarily belong to the workplace, but first to our own self. This perspective creates a much greater individual responsibility for one's own path in life and satisfaction (Gonzales, 2015). Equally, this perspective dilutes critical attitudes towards social inequalities. Individuals are trained to believe that what is not directly manageable by them, like life experiences, has to be treated as a lesson for someone, it has a purpose. If one has a look at the 
aims of what spiritual changes suggests, it is hard to deny the link with principles of neoliberal governmentality exposed before. 'Technologies of the self' are activated from the beginning: apprentices have to learn how to manage their own conscience and thoughts. They have a non-imposed guidance on how to create their own well-being, on how to 'be the best version of themselves'.

\section{The state from which change begins: What exactly requires change?}

What I am is a given. [...] What I become is a process that, with a more awakened attention, I hope that I'll be able to coordinate to such an extent so as to raise my life instead of lowering it or leaving it to chance to unfold without my intervention (Andreescu, 2015: 22).

The examples of situations that require change presented by authors, experts in the field or practitioners of spirituality, differ significantly. All these sources stress the uniqueness of the human being, and this means that these situations cannot be generalized. I found out later, from interviews and book analyses, that what triggers the desire to change the self is less relevant - it was in the past - what is truly important is that the intention, aspiration to change has occurred. Moreover, I was told explicitly that this moment is not quite relevant:

Change comes when you're ready, never before (A., 35 years old, woman, Yoga practitioner).

Each person is different. For some maybe it's about specific words and from there they get interested. For others it may be about events: some events may be simple, for others they have to be complex. So far from what I have seen, from what I have noticed, there is a range so great that it's really hard to create a pattern or a mode, an algorithm to identify if a situation fits or not. To persuade a person to become active on that side, I at least still have not found that 'common' aspect (F., 29 years old, man, Reiki therapist and IT engineer).

Practitioners told me that there are no specific causes that bring the desire to change, just as there is no universal recipe for that change to occur. As Daniela Andreescu (2015) - one of the analysed authors - mentioned, the range of positive changes and conscious transformations is fairly diffuse. Sometimes changes in the day-to-day life are very subtle and happen on the level of details. But the fact is that change involves a general upgrade of life on all levels. One of the main commitments promised by these new forms of spirituality is changing the self, not through means that are exterior to the self but through the very discovery and employment of one's own abilities: Be the change that you wish 
to see in the world ${ }^{3}$. Personal development is an individual process and directly determined by our own outreach, streamline of anything, self-motivation and self-accountability (Salome, 2008; Szasz-Soares, 2014). This idea, specific to the new forms of spirituality, couldn't have occurred outside a neoliberal context, one that pushes the concept of freedom and encourages subjectivity. From the perspective of a significant part of specialists and practitioners "It's up to you to choose what you want and how your life will be" (Zărnescu, 2014:8); the external factors are almost missing or ambiguously mentioned. The only thing that is necessary is the change per se.

The individual search for meaning (Bown and Williams, 1993) becomes one of the main responsibilities of the person engaged in the process of change, necessary in identifying and developing the authentic self (Flanagan and Jupp, 2007; Osho, 2015; Urban, 2016, Gonzalez, 2015). All the books promoted a focus on a holistic approach of change, one that is aiming equally at the mind, body and soul, and directly manageable by the individual. The responsibility for one's own life and well-being becomes a personal one. So the responsibility at a social level is attenuated, but this never comes up explicitly:

The responsibility is yours entirely. If there is a failure, that is it. The responsibility for failure lies on you. If you succeed, you succeed. The responsibility for success lies on you as well (Osho, 2015: 75).

[Change] is about freedom and about assuming your own life beyond your wildest dreams. [...] The ability to achieve anything you put your mind to (Zărnescu, 2014:15).

Love yourself and live in harmony with your spirit. If you do so, your life will run smoothly and you will feel at peace. This is all it takes (Choquette, 2009, fourth cover).

With the exception of some materials, that are often discredited within the field - that propose through a number of steps and techniques a rapid improvement of mind, body and soul - the change is not necessarily seen as an easy process. More often than not, authors of the books claim that spiritual transformation is not easy (Andreescu, 2015; Demetrescu, 2013; Sandner, 2015) especially on one's own, just because it is not truly understood (Andreescu, 2015). Thus the guiding offered throughout personal development can be justified and finds meaning, alongside the multitude of resources and materials available. The change cannot be understood as a quick fix and it cannot be compared to microwave recipes ${ }^{4}$, it is a process. What is indeed a quick fix is the birth of the

3 This extract from Mahatma Gandhi is widely used in the field of spirituality; I encountered this quotation in interviews, texts and blogs.

4 Name given in a pejorative way to discredit a part of the industry that promotes quick methods of body-mind-soul improvements. These methods take for granted some directives, they are applied universally to anyone who wants to improve certain aspects of their self and they use introspection only to a very small extent. 
desire for change; awareness of the need for change - as interviewees said cannot be generalized and is not bound to a particular event in the life of an individual. We are unable to determine what triggers the change, but we can identify a pattern that concerns the issues that need to be changed and the techniques to follow.

Well, the soul always knows it, and guides us too! What we have to do is be aware of the presence of our soul inside. Believe me, you can listen to it. But to be able to listen to your inner self takes a lot of practice, and this practice is best known as meditation. So I believe including this very practice of listening to the soul in our daily life, acts as the first and very important step towards finding spirituality in our daily life. As they say, 'Keep calm and meditate' (P., 38 years old, man, 'modern shaman').

\section{What does the project of changing the self actually mean?}

As I mentioned earlier, the moment in which change occurs, common in all the interviews, is when it is supposed to come: 'It comes when you're ready! Then you'll find the shaman, coach, book or course. It comes at the right time just because that is what is right for you!' (F., 29 years old, man, Reiki therapist and IT engineer). 'It doesn't come by chance!' (A., 35, woman, Yoga practitioner), but this moment cannot be premeditated, only understood after it has happened. The fact is that there must be a moment for that change to ensue, even if change is not 'instant' but a continuous process, "it needs a starting point, either chaos or paradox. [...] How I am is a given. How I become is a paradox." (Andreescu, 2015:22). As it becomes evident from the excerpts from books and interviews, the change does not come with pressures or constrains, it has to come naturally and suitably for the subject (Osho, 2007; Robbins, 2011; Tolle, 2009). As Foucault argued in his writings on neoliberalism, "nothing imposes an obligation, and everything, including one's own mind, body, and emotional state is a resource, a force to be excited, an opportunity to be developed, exploited, or leverage for advantage in a world of competitive actors" (Foucault in Binkley, 2014: 3).

The project of self-development implies first of all an evaluation of the relationship to the present. Understanding the importance of focusing on the present seems easy, but in practice it is a laborious process that requires a lot of work, theoretical and practical training. The exercises suggested by authors, trainers and practitioners include a great range of options and are classified according to the level of training of the practitioner (Hedges5; Ferrini, 2007;

5 https://www.youtube.com/watch?v=1qeaE5tf2-s. 
Sandner, 2015; Tolle, 2009, 2012) from simple exercises that focus on posture, breathing, visual, tactile and olfactory to long meditation exercises. There are exercises that aim at achieving a state of living in the now instantly, but the effect felt by practitioners is ephemeral; total living in the now requires thorough mental preparation and a very intensive work with one's own self. I have frequently heard trainers say: "Living in the present means focusing on what is happening right now, enjoying it, and making the most of it" (C., 26 years old, man, motivational trainer). Thus, as practitioners argue, daily life becomes more enjoyable, less burdened by worries and less stressful.

Amy Cuddy's book can provide a good example for inexperienced readers; she discusses at length presence, giving it a widely accessible meaning as "a state of contact with our true thoughts, feelings, values and potential, and also the ability to express them freely. That is it" (Cuddy, 2016: 36). This state is present in moments when the subject feels confident about his own capabilities and allows himself/herself to focus intensively on his/her truest self. The presence that Cuddy is talking about is different from the state of presence that occurs in spiritual professionals' discourses. In this case, presence is achieved by gradual changes that do not imply a spiritual revelation and hard work on total inward transformation. It is accessible to everybody and happens in the everyday life. Augmenting the state of presence requires practice, a good coordination of the psyche (self-inducing the state) and body posture. At this level, the easiest one, presence helps to achieve success and enables a much better management of day-to-day stressful situations, working like a panacea; that's why, presence knows success through employees. Cuddy says:

The state of presence arises from the fact that we believe our own story. When our story is not credible for ourselves, we are not authentic - in a way, we deceive ourselves and others. It has even been proven that this self-deception can be observed from the outside, because we lose our self-confidence and start to manifest dissonant verbal and nonverbal behaviours (2016:54).

The present moment is the only thing where there is no time. It is the point between past and future. It is always there and it is the only point we can access in time. Everything that happens, happens in the present moment. Everything that has ever happened and will ever happen can only happen in the present moment. It is impossible for anything to exist outside of it (F., 29 years old, man, Reiki therapist and IT engineer).

In 2015, in the top five best-selling books of Curtea Veche Publishing, a well-known publishing house in Romania ${ }^{6}$ there are three books from the field of personal development, and one of them is the much publicized Power of Now

${ }^{6}$ http://www.mediafax.ro/cultura-media/topul-celor-mai-vandute-carti-in-2015-foto-14943347. 
by Eckhart Tolle. Although the ideas presented here are related to the ontology of the present and conscious living, this type of reading differs substantially from that of Amy Cuddy. Tolle explicitly proposes a type of reading that requires on the one hand much attention, and on the other thought or meditation. The stake underlying all of the book is to produce a radical transformation of the subject in terms of self-discovery as the most important resource for achieving enlightenment. Spirituality thus presented is not esoteric or paranormal, it does not imply endless theological and philosophical debates, but requires a radical transformation of the subject. Consciously living in the present requires detachment from projections about the future, fuelled by experiences related to the past, and a much better concentration on everything that is happening in the present moment. As shown in the international bestseller The Monk who sold his Ferrari (Sharma, 2013), the art of mind control and spiritual awakening is strictly related to the present, it cannot be obtained from the past or from projecting the future. Emotions are attached to experiences associated with past events or projections about the future. In addition to that, just by learning the ability to live in the present enables the possibility of absolute living. In the present all senses are exploited to their maximum capacity and all the other changes that I will discuss in what follows, are conditioned by acquiring the ability to live in the present.

Changing the self in a spiritual context means, besides living in the present, also changing the view on happiness. As it became apparent from my interviews, it is not enough to live. You must live happily. "The existence has no meaning and colour unless it becomes the place and time of happiness" (M., 34 years old, English teacher; practitioner). To support the therapeutic effects of happiness and to provide a guarantee for their practices, many experts have appealed to already acknowledged studies from positive psychology or medicine. For example, Lyubomirsky's (in Winfield, 2013) study on happiness demonstrates that spiritual people are generally happier, have superior mental health, cope better with stressors, have more satisfying marriages, use drugs and alcohol much less, are physically healthier and live longer than non-spiritual people (Lyubomirsky in Winfield, 2013). Especially from the perspective of those urban and high-skilled people that practice different forms of spirituality, no one is responsible for someone else's happiness or sadness, but each one is responsible only for their own feelings. In order to achieve happiness, new forms of spirituality offer a large range of options: from yoga classes to aromatherapy, Bowen techniques, meditation, holotropic breathing or music therapy suggested by positive psychology studies. 
When I feel down, energetically, I stop everything. I'll do a simple breathing exercise, eight counts, and then I'll resume the exercise for five more times. It's important to break off anything, to concentrate only on yourself and your breathing. The results will soon appear. The body rebalances, I reach the state of tranquillity and all worries are cleared. In fact, what I'm saying is that happiness is stored inside us, we just have to find the right key to release it (A., 35 years old, yoga practitioner).

I don't think happiness is found in substances, only within your being, eager to connect to the Universe's energy, not someone else's energy (T., 28 years old, woman, TethaHealing practitioner).

Nutrition matters a lot, in the sense that we are influenced by the energy we ingest and if we have contact to food that is energetically imbalanced, this comes at the expense of our energy. Of course, we can rebalance energetically, but that is extra-work and a very hard one, so then we're better of paying attention to what we eat (R., 30, woman, afterschool trainer).

At a seminar, we were recommended a very nice exercise. We were all together, and the first time it was a little awkward to laugh, even mechanically, but it became contagious. It really works! (F., 29 years old, man, Reiki therapist and IT engineer).

As consequences of living in the present, some of the prospects that spiritual development promises are: concentration, confidence in one's own abilities and detachment from problems. As almost all the interviewed subjects have revealed, they feel many of the day-to-day problems are made up by our own thinking, by comparing with others. To avoid such inconveniences, the project of personal subjectification introduces ways through which the individual gains the ability to increase the degree of self-confidence by the ability to detach oneself from problems and from the others. Thus, thinking itself becomes 'material' and directly manageable, as does happiness. In the project of self-development, the meaning of life must be derived from the interior and should not be sought outside of it. Each individual is responsible to identify and intensify 'one's own best version of themselves':

Americans have a saying 'Get Alive'. Meaning what?! Meaning that you have only one life, your own, so live this one because you don't have time for another! Or more bluntly: You watch out for YOURSELF!!!' (A., 35 years old, woman, Yoga practitioner).

On the other hand, you get legitimacy as your own authority. You no longer need someone from the outside to validate you and you have some inner certainties that guide you. More than just certainties, because that is pejorative. Ushering truths. It's just like a spot where all things in your life concentrate.

Compared to institutionalized religions, new forms of spirituality, as Osho says, create a chaos (Urban, 2016). Perhaps Osho's most pervasive influence has been on the loose and eclectic body of contemporary spirituality commonly 
referred to as New Age: "various beliefs and practices that are by no means singular or monolithic but in fact widely diverse and heterogeneous" (Urban, 2016:30). In this chaos, like in neoliberalism, nothing is mandatory anymore, there are no more prerogatives. Everyone applies what works because everyone is responsible for his/her choices; only the self, connected to the Universe, can decide what's right for oneself. I would say that the diversity and abundance of widely eclectic forms of spirituality is possible due to this chaos. Individuals are looking for instruments that facilitate their (social) lives and adopt what they think is proper for them, in terms of efficiency and accessibility. These forms of spirituality, practiced by more and more people in urban areas, cannot be regarded merely as simple, passive echoes of globalization, but instead their active catalyst role in the contemporary society must be understood (Urban, 2016). They do not pull individuals out of the society, on the contrary, they enhance the self in order to increase one's capacity of adaptability in a given system. Essentially, the personal development project greatly serves 'the interests of society', in the sense that the new person manages to become more efficient, more creative, proactive, determined to succeed and prosper, to become responsible for their own wellbeing.

It is not necessarily obvious, but a significant part of fieldwork shows that some forms of spirituality benefit capitalism and consumerism. Prosperity must be a part of the personal development agenda; it does not only aim at economic capital, but it also refers to the physical, mental and spiritual development. To be prosperous one must remain anchored in society, develop positive thinking and understand the law of attraction. The universe - as described by spiritual facilitators or trainers - is a great meritocratic system, in which the law of attraction works well. This refers to the ability of each individual to attract in his/her life those factors that one is thinking about: if one's thoughts are good, the Universe will reward you with goodness. As Osho asserts: "Capitalism is a humanistic system which gives full freedom to all kinds of people, and in all directions of life, to grow and be themselves [...] The death knell of capitalism may turn out to be the death knell of man himself" (Osho in Urban, 2016:56). Besides the personal level, changing the self fits very well with the capitalist system and the new type of work enforced with the advent of corporations. Technological advances, new global politics, together with changes in the view of imagining work at an organizational level contribute to massive shifts regarding the perception of labour and the way employees position themselves regarding their working activities. In order to maintain its mobilizing powers, capitalism needs to call up resources from outside of its immediate economical reach, permeating all the other relevant ideologies from the larger cultural context in which it develops (Boltanski and Chiapello, 2005). Starting from the 
early 2000s and intensifying in the last years in Romania as well, positive psychology and all the emergent alternative religious forms seem to represent these ideologies.

Corporate spiritualities (Flanagan and Jupp, 2007) promote the idea of maximizing the employee's potential, encouraging a competitive and productive unique individual, but in order for these strategies to function on the long run, employees need to develop all these 'abilities'. The developmental triad following the personal, professional and spiritual evolution of the individual almost becomes a chore that needs to be fulfilled if one wants to embrace actual working standards. All of these processes represent individual actions, although they can be actualized in collective settings, because each and every person focuses on his or her own self, trying to make things better for his or her self-interest (Giacalone and Jurkiewicz, 2003). Due to these new forms of spirituality, companies interact with people who find their own balance, are mentally stable, find motivational resources in their actions, know what they are aiming for, get involved in difficult tasks, aim to develop their careers and find resources to sustain this effort, are eager to compete and are extremely well-trained. At the same time, the new employees were socialized to believe that prosperity and success can be and should be achieved, but only if they manage to properly adapt and display self-discipline.

It is relevant to discuss one more aspect: the relation between individual practitioner of spiritual development - and society. Most of the respondents are not interested on what others think about them, and this is one of the major changes in their lives. They learned how to live in harmony with social norms and at the same time to feel free. I would like to point out the fact that, for them, achieving a higher level of spirituality does not mean living in a specific alternative society. On the contrary, the great challenge for them is to be their best version within the contemporary urban society. As one respondent mentioned "the challenge is not to live in isolation, there you don't have temptations and you could be calm and meditative all day long; the challenge is here!" (M, 26, woman, therapist). Perhaps the most suggestive quote is: Be the change you want to see in the world repeated by some respondents when I asked them to think about their relationship with society. As Zinnbauer et al. have noted, to see "spirituality as a solely phenomenon is to overlook the cultural context in which this construct has emerged, and the fact that spirituality is not experienced or expressed in a social vacuum" (1999: 902). It is no coincidence that the popularity of spirituality has grown in a culture that values individualism and rejects conventional authority (Zinnbauer, 1999). 
As your connection with the Universe becomes more and more intense - in fact increasingly conscious - you'll see that you'll start to lose some of your interest for others. Please, don't understand that in the sense that you no longer care, but you realize that there is no use in judging others, and just because you start to not look at others, you start to not care about what others say about you (T., 28 years old, woman, TethaHealing practitioner).

\section{Conclusion}

Based on analysing interviews, discussions with trainers and the literature on spiritual development, I claim that the main aspects of self-development imply changes on the vision of self, time, happiness, work and society as a whole. As the fieldwork denotes, the project of the self has the following features: success orientation, an emphasis on healing and a desire to be modern. It combines eclecticism, syncretism, optimism, a tendency towards believing in life-long personal growth and an emphasis on psychic and mental power. It is this pursuit of special interest for persons with higher levels of education and with professions that need concentration, performance, adaptability and, why not, creativity. In almost all the situations analysed, the process of spiritual development has a clearly defined purpose and immediate results that concern only the practitioner and the relationships that he/she establishes. Emphasis is laid on unique experiences, the uniqueness of life that must be 'consumed' here-and-now. All these mentioned characteristics are in accordance with the current economic and social conditions of neoliberalism. The research shows that the process of self-development greatly serves as a technology of neoliberal governmentality.

Spiritual development becomes in fact an individual project - for the subjectifying self - and equally a transnational project that involves many more factors hinted at here without detailed analysis. The form of spirituality that the individual chooses is not that relevant, because the global forms emphasize personal spiritual experience and an ideal personal freedom. Throughout this process the individual develops all those abilities that one considers necessary for increasing self-esteem and to detach from problems that do not relate to oneself or to one's own well-being. The personal development project, in a spiritual framework, is much more complex than it might seem at first glance. It has the capacity to permeate all forms of daily life; it interests employers and, at the same time, it interests the entertaining industry that can thusly suggest new ways of spending leisure time, new forms of spiritual tourism and also new forms of consumerism. The same project also includes transnational networks, ideas and capital from many corners of the world. These spiritual movements coming in part 
from Asia offer a powerful alternative to the usual narratives of globalization. "Cultural ideologies flow not only from the West to the rest" (Srinivas in Urban 2016:5) but also from India and other parts of Asia, revealing a far more dynamic and multidirectional global flow of religious forms (Urban, 2016).

As far as future studies on spiritual development are concerned, I propose a closer look at the differences between those subjects that are very close to the interests of neoliberalism and those who adopt alternatives modes of living and manifest anti-consumerist attitudes. I think that is necessary to make this distinction when we are looking at spirituality and spiritual development. Due to the fact that my fieldwork is ongoing I will have a closer look at the similarities and distinctions between these two categories that have the same fundaments. The analysis of both categories will offer a better understanding of how neoliberal governmentality works and how it adapts itself to satisfy the demands of the population.

\section{REFERENCES}

Binkley, S. (2007). Governmentality and Lifestyle Studies. Sociology Compass, 1(1): $111-126$.

Binkley, S. (2011). Happiness, Positive Psychology and the Program of Neoliberal Governmentality. Subjectivity, 4 (4): 371-394.

Binkley, S. (2014). Happiness as Enterprise: An Essay on Neoliberal Life. Albany: Sunnypress.

Boltanski, L., Chiapello, E. (2015). Noul spirit al capitalismului [The New Spirit of Capitalism]. Iași: Editura Universității 'Alexandru Ioan Cuza'.

Bown J., Williams S. (1993) Spirituality in nursing: a review of the literature. Journal of Advances in Health and Nursing Care. 2(4): 41-66.

Carrette, J., King, R. (2005). Selling spirituality. The Silent Takeover of Religion. London and New York: Routledge.

Flanagan, K., Jupp, C. P. (2007). A Sociology of Spirituality. Cornwall: Ashgate.

Freeman, C. (2007). The 'Reputation' of Neoliberalism. American Ethnologist, 34(2): $252-267$.

Foucault, M. (1988). Technologies of the self. In L. H. Martin, H. Gutman, \& P. H. Hutton (Eds.), Technologies of the self: A seminar with Michel Foucault (16-49). London: Tavistock.

Foucault M, (1991). Governmentality. In G. Burchell, C. Gordon, \& P. Miller (Eds.) The Foucault effect: Studies in governmentality (87-104). Chicago: University of Chicago Press.

Giacalone, R.A., Jurkiewicz, C.L. (2003). Handbook of workplace spirituality and organizational performance. New York: M.E. Sharpe. 
Gonzalez, G. (2015), Shape-Shifting Capital. Spiritual Management, Critical Theory, and the Ethnographic Project. London: Lexington Books.

Heelas, P. (2008). Spiritualities of Life. New Age Romanticism and Consumptive Capitalism. Oxford: Blackwell Publishing.

Hefner, R. W. (2010). Religious Resurgence in Contemporary Asia: Southeast Asian Perspectives on Capitalism, the State, and the New Piety. The Journal of Asian Studies, 69(4):1031-1047.

Miller, P., Rose, N. (2008). Governing the Present. Administering Economic, Social and Personal Life. Cambridge: Polity Press.

Rose, N. (1990). Governing the Soul. The Shaping of the Private Self. London and New York: Routledge.

Rose, N. (1998). Inventing Our Selves: Psychology, Power and Personhood. Cambridge: Cambridge University Press.

Rose, N. (2007). The Politics of Life Itself: Biomedicine, Power, and Subjectivity in the Twenty-First Century.

Schwartz, B. (2000). Self-determination: The tyranny of freedom. American Psychologist, 55:79-88.

Urban, H. B. (2016). Zorba the Buddha. Sex, Spirituality, and Capitalism in the Global Osho Movement. California: University of California Press.

Winfield., N. (2013). The Seekers: Do Spiritual Practices Lead to a Sense of Well-being? http://web.stanford.edu/group/journal/cgibin/wordpress/wpcontent/uploads/ 2013/06/Winfield-.pdf

Zinnbauer, B. J., Pargament, K. I., Scott, A. B. (1999). The Emerging Meanings of Religiousness and Spirituality: Problems and Prospects. Journal of Personality, 67(6): 889-919.

\section{Documents used}

Andreescu, D. (2015). Conversații cu tine. Relații și comunicare prin metoda ESPERE [Conversations with you. Relationships and communication through the ESTERE method]. București: Herald.

Choquette, S. (2009). Răspunsul este simplu...: iubește-te pe tine însuţi și trăiește la unison cu spiritul tău! [The Answer is Simple...: Love Yourself, Live Your Spirit!], Brașov: Adevăr Divin.

Cuddy, A. (2016). Prezența: Găsește-ți echilibrul între corps și minte în fața marilor provocări. [Presence: Bringing Your Boldest Self to Your Biggest Challenges], București: Publica.

Demetrescu, S. (2013). Din Tainele Vieții și ale Universului. [The Secrets of Life and Universe]. Oradea: Emet.

Ferrini, P. (2007). Cum să creăm o relație spirituală [How to create a spiritual relationship]. București: For You.

Osho (2007). Revoluția interioară [Revolution]. Bucuresti: Herald.

Osho (2015). Libertatea. Curajul de a fi tu însuți. [Freedom: The Courage to be Yourself]. București: Litera. 
ANDRADA TOBIAS

Robbins, A. (2011). Puterea Nemărginită [Unlimited Power]. București: Amaltea.

Salome, J. (2008). Curajul de a fi tu însuți [If Only I'd Listen to Myself]. București: Curtea Veche. Sandner, U.Y. (2015). Puterea ta interioară [Your interior power]. Timișoara: Gordian.

Sharma, R. (2013). Călugărul care și-a vândut Ferrari-ul [The Monk Who Sold His Ferrari]. București: Vidia.

Szasz-Soares, L. (2014). De la grădinar la business coach. [From gardener to business coach]. Cluj-Napoca: Lorand Szasz-Soares.

Tolle, E. (2009). Un nou pământ: Trezirea conștiinței umane [A New Earth: Awakening to Your Life's Purposes]. București: Curtea Veche.

Tolle, E. (2012). Puterea Prezentului [The Power of Now]. București: Curtea Veche.

Zărnescu, D. (2014). Esenta Eficienței [The Essence of Efficiency]. București: Stepout Publishing House.

\section{Youtube sources}

Kristi Hedges - Power of Presence

https://www.youtube.com/watch?v=1qeaE5tf2-s (Accessed in October 2016).

\section{Websites}

http://www.mediafax.ro/cultura-media/topul-celor-mai-vandute-carti-in-2015-foto14943347 (Accessed in November 2016). 